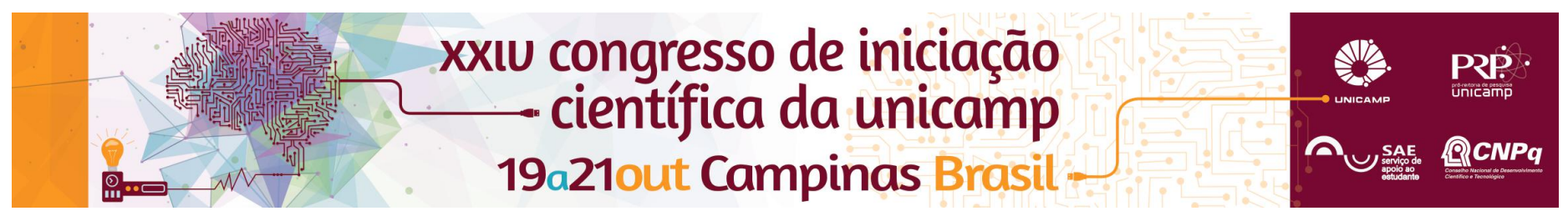

\title{
As imagens dos "meninos do tráfico": a malha que entrelaça os menores infratores da Fundação Casa
}

\section{Elena D. Parravicini}

\begin{abstract}
Resumo
A partir da pesquisa de campo realizada em uma oficina de CineDebate na Fundação Casa Andorinhas em Campinas, esse trabalho irá discutir as formas através das quais os meninos envolvidos no "mundo do crime" se vêem e como acreditam que são vistos. Baseado na ideia de meshwork, proposto por Tim Ingold, esse trabalho percorre os fios vitais que entrelaçam os menores infratores da Fundação Casa, buscando evidenciar um desiquilíbrio de poder na construção das imagens desses interlocutores.
\end{abstract}

\section{Palavras-chave:}

Fundação Casa, imagem, meshwork.

\section{Introdução}

Essa pesquisa surgiu com a proposta de analisar a disputa pela construção da imagem de "traficante de drogas", a partir da comparação entre a forma como os jovens "envolvidos" com o tráfico se veem e as imagens que os retratam no cinema brasileiro. No entanto, o trabalho de campo realizado em uma oficina de CineDebate com 18 meninos internos da Fundação Casa Andorinhas na cidade de Campinas, apresentou a necessidade de uma ampliação do escopo desse estudo.

A oficina propiciou a criação de um espaço potente de diálogo entre a pesquisadora e os meninos, bem como entre eles mesmos. Nesse ambiente, os educandos apresentavam suas narrativas individuais da vida que levavam no "mundão", enfatizando principalmente, a família, a "quebrada" e o crime. Além disso, discutiam sobre as relações de força presentes no nosso convívio social - como questões referentes ao machismo e racismo - além de narrarem seu cotidiano "na prisão", onde se apresentavam como um grupo de vocubulário e rituais próprios que se adaptavam às dinâmicas e exigências da Fundação Casa.

Além das experiências vivenciadas no campo, o objetivo de comparar a iconografia cinematográfica com as autoimagens dos "meninos do tráfico" foi ampliado pelas reflexões à respeito do meshwork, proposto por Ingold ${ }^{1}$. É baseando-se em tal concepção que abordo, nessa pesquisa, as imagens como coisas: longe de serem um objeto fechado sem interação com o "mundo real", elas não se esgotam no nível da representação, mas despertam e modificam a maneira como os meninos pensam o que os cerca e a si mesmos.

\section{Resultados e Discussão}

Inicialmente, a pesquisa foi dividida em dois momentos distintos: a parte teórica de levantamento bibliográfico e a parte resultante das experiências vivenciadas no campo. O primeiro momento teve como foco as possibilidades do uso de ferramentas da Antropologia Visual para analisar as autoimagens dos interlocutores da pesquisa, bem como da iconografia referente a esses jovens no cinema brasileiro contemporâneo. É a partir da ideia de meshwork proposta por Ingold que abordo, nesta pesquisa, as como coisas vivas, é afastada a ideia de que as imagens são meras representações ou imitações da realidade. A busca de uma relação quase direta entre cinema e sociedade é substituída neste trabalho pela imersão das imagens no meshwork ou malha.

O segundo momento, o trabalho de campo, é essencial para essa pesquisa, já que expressa a metodologia defendida por Ingold no fazer antropologia "com os interlocutors" e não apenas "sobre" estes. Nesse contato os meninos mostram, de maneira geral, uma preocupação com sua imagem, sempre interessados em saber como as pessoas ao redor os vêem especialmente eu. E, apesar de pousarem para as fotos com "cara de mau, coração de pardal", eles parecem se incomodar em despertar medo nas pessoas do "mundão". Isso ficou evidente no dia em que saíram da centro para visitar uma exposição fotográfica no centro da cidade. Lá, eles se mostraram incomodados com as roupas que usavam e como as pessoas ao seu redor os observavam. A oficina de fotografia foi um espaço importante para eles falarem de suas mudanças físicas e psíquicas, além de produzirem uma autorreflexão acerca de sua trajetória na Fundação Casa e no crime.

\section{Conclusões}

O poder das imagens-coisas é evidenciado pelos efeitos da própria oficina, que utilizava as imagens como ferramenta para despertar coisas e discussões nos - e entre - os meninos. Deve-se ressaltar que por se tratar de uma ação educativa, a forma como essas imagens os afetavam estava muito relacionada aos objetivos da oficina. Assim, não poderia afirmar de que maneira exata o que as imagens - por si só - despertavam neles. Trata-se de um processo interno complexo de dificil inteligibilidade e acesso, principalmente em um contato de três horas semanais em uma relação moldada por diversas normas da própria instituição. No entanto, o trabalho de campo continua em andamento até o final de julho através da oficina de fotografia, na qual os meninos produzirão mais imagens a respeito de si.

\section{Agradecimentos}

Agradeço à Karina Biondi pela orientação, paciência, disponibilidade e carinho.

\footnotetext{
INGOLD, Tim. Key debates in anthropology. Psychology Press, 1996.
} 